\title{
Analysis of Drug Logistics Management in the Pharmacy Installation of Klaten District Health Office
}

Listyorini Wulandari ${ }^{1}$,
Indasah ${ }^{2}$,
Byba Melda ${ }^{2}$
Magister of Health Study
Program of Institut Ilmu Kesehatan
STRADA Indonesia
${ }^{2}$ Lecturer of Institut Ilmu
Kesehatan STRADA Indonesia
Email:
ririn_2589@ymail.com

Received : October 12, 2019

Accepted : February 13, 2020

Published : May 12, 2020

\begin{abstract}
Drug is an element supproting the health care system. Logistics management start from the planning process, procurement, storage, distribution, recording and reporting drugs. The purpose of the research was to explore drug logistic management at the pharmacy installation in the working area of Klaten District Health Office. Research design uses descriptive qualitative research. Data collection used indepth interview techniques with a total sample are 12 informants. From the results of the research it was found that drug planning at the health center pharmacy installation was carried out by the drug manager himself or in a team with the assistant pharmacist or treasurer of the health center. The drug needs planning process in the health center is carried out by recapitulating reports from the health center and the other units in the Usage Sheet and the Drug Request Sheet (LPLPO). Drug planning is carried out every month. Drug procurement is carried out by the consumption method and carried out through e-catalog once a year with buffer stock of one and a half years. The drug storage layout is accordance with provisions, safeguarding the quality of the drug by placing drugs on the pallet and shelves but there is no temperature measurement. Examination of drugs that come, drugs needed by the health center and drug distribution have been carried out according to the procedure. The recording and reporting of drugs in the health center uses sympus whereas in other units manually using LPLPO.
\end{abstract}

Keywords: Distribution, planning, procurement, recording and reporting of drugs, storage 


\section{INTRODUCTION}

Drugs are ingrediens or alloys of materials used to influence or investigate the physiological system or pathological conditions in the framework of the determination of diagnosis, prevention healing, recovery of health and contraception including biological product (Ministry of Health, 2006). Drug is a supporting element in the complete plenary health service system (promotive, preventive, curative and rehabilitative). The need for drug cannot be delayed or replaced. Almost every health service intervention always uses drugs (Rumbay et al, 2015).

Drug management is an activity which includes the stages of planning, procuring, storing, distibuting and using drugs by utilizing available resources. The main purpose of drug management is the availability of good quality drugs, spread evenly, with type and amount that matches the needs of basic health service (Anshari 2009).

District/ City drug management is the full responsibility of the District/City goverment. Start from aspect of planning drug needs for basic health service based on a bottom up system, calculating of drug needs planning, as well as coordinating planning of drug needs from several funding sources (Ministry of Health, 2008).

One of the technical implementation units of the Klaten District Health Office that carried out drug management was the Pharmacy Installation of District Health Office. The function of this pharmacy installation is as a place for pharmacy work to take place and responsible for managing, receiving, storing, and distributing drugs to health service located in the working area. The number of pharmacy staff in the working area of the Klaten District Health Office are 38 people with 6 pharmacists and 32 phramacy technical personal.

From the preliminary data survey in the Pharmaceutical Installation of Klaten District, drug planning was carried out using a consumption method by looking at the consumption amount of drug use in the previous year plus $10 \%$ of the drug. Planning and procurement of drugs have not used a combination of consumption and morbidity or epidemiological methods.

Excessive availability of drugs will experience quality degradation or expiration. The availability of drugs and vaccines in the Pharmacy Installation of Klaten District Health Office in 2017, the drug captopril tab and glibenklamid had an excessive level of availability (captopril $159.64 \%$ and glibenklamide $155.93 \%$ ) so that there was still a lot of drug stock at the end of the year (captopril $58.24 \%$ and glibenklamide 57.25\%). If the availability of drugs has shortage, it will reduce the quality of health services and treatment interventions become irrational. The needs for dexametasone tabs and ors salts is not sufficient where dexametasone availability is only 259,000 while the need for 2017 is 389,400 and the availability of ors salts is only 56,500 bags while 84,750 bags are needed. The purpose of this research was explore the implementation of drug logistic management at the pharmacy installation in the working area of Klaten District Health Office.

\section{METHODS}

In this research using descriptive qualitative methods. The location of this research is health center pharmacy installation working area of Klaten District Health Office. The research was carried out to the drug managers of the health center in the working area of Klaten District Health Office, both inpatient health centers and non-inpatient health centers. The research was conducted on May 14, 2018 to July 6, 2018.

The sampling technique in this research used purposive sampling with a total of 12 informants. Source triangulation was carried out to the Head Pharmacy Installation of Klaten District Health Office while method triangulating by observed the Usage Sheet and Drug Request Sheet (LPLPO), delivery letter and observation in the drug storage warehouse.

The data collection process using semi structured in depth interview method was carried out to the drug managers of the health center pharmacy installation who were willing to become informants. Results of the informan's answers immediately recorded on mobile phones as recording devive and documetation without regard to the informant's face (with permission and informan's knowledge). 


\section{RESULT}

\section{The Process of Request Preparation and Planning of Drug Requirements at The Health Center Pharmacy Installation}

The result of this research revealed planning process at the health center pharmacy installation is carried out every month beginning with the recapitulation of reports from the main health center along with other units in LPLPO then reported to the pharmacy warehouse as a drug request for the following month. There are also health centers than drug planning by procuring themselves once a year with a buffer of one and a half year.

\section{Drug Planning and Schedule of Activities for Preparing Operational work Plans}

The result of the research revealed that drug planning at the health center pharmacy installation was carried out by drug managers themselves, both at the beginning of the month and the end of the month. Drug planning is also carried out a team by the drug manager with the pharmacist assistant or by the pharmacist with the treasurer of the health center.

\section{The Method Used for Planning for Drugs Procurement}

The results of the research revealed that planning for drugs procurement at the pharmacy installation was carried out using monthly usage method. Drug procurement is carried out onece a year with buffer stock of one and a half years.

\section{Drug Procurement at the Health Center Pharmacy Installation}

From the result of the research revealed that drug procurement at the pharmacy installation was carried out once a year outside the drugs provided at the pharmacy warehouse and ordered through ecatalog. Drug procurement is carried out by considering the doctor's proposal, medical center, maternity homes and hospitalization.

\section{Spatial Arrangement and Drug Storage}

From the result of the research revealed that spatial arrangement and drug storage at the health center pharmacy installation was carried out properly according to the procedure, where the drug was stored in a separate room with the preparation of drug stocks alphabetically, according the dosage form, with FIFO (First In First Out) and FEFO (First Expired First Out) system.

\section{Safeguarding the Quality of Drug}

The result of the research revealed that safeguarding the quality of drug at the health center pharmacy installation was carried out by the drugs is stored in a drug warehouse that installed with air conditioner or fans, drug placed on pallets, shelves, refrigerators or chain cold.

\section{Examination of Drug that Come}

The results of the research revealed that the drug has come were checked according to the procedure where the drug checked one by one start from the name of drug, number, batch number, volume and expiration date.

\section{Drug Distribution Mechanism at the Health Center Pharmacy Installation}

The results of the research revealed that drug distribution from health center to auxiliary health centers and the other units was carried out once a month or two months with LPLPO taking into account the availability of drugs at the health center.

\section{Drug Needed by the Health Center}

From the results of the research revealed that the drug needed by the health center were routinely dropped once regularly by health office. 


\section{System for Recording and Repoorting Drug at the Health Center Pharmacy Installation}

From the result of the research revelaed that the drug recording and reporting system at the health center had used sympus although in some health center it had not run optimally while the recording and reporting of drugs in auxiliary units were still manually using LPLPO.

\section{DISCUSSION}

\section{The Process of Request Preparation and Planning of Drug Requirements at The Health Center} Pharmacy Installation

Planning of pharmacy needs is an activity process in the selection of types, quantities and prices of pharmacy supplies that are accordance with needs and budget to avoid drug vacancies by using accountable methods and predetermined planning bases (Herlambang, 2016). The purpose of drug planning is to determine the type and amount of drugs and drug supplies that are appropriate in accordance with the needs of basic health services include the health program drug that have been determined (Ministry of Health, 2010).

The result of the research revealed that the implementation of the request and drug planning at the health center pharmacy installation in the working area of Klaten District Health Office was carried out by the health center drug manager at the beginning with of each month, start from recording reports from the auxiliary health ceters, Master Health Centers and other units in LPLPO then reported to the pharmacy warehouse as a drug request for the following month.

Different from the Mangindara et al (2012) research, which revealed that planning of the drug needs in Kampala Health Center was planned by the person responsible for the drug on a regular basic every period of needs, namely four times a year, drug delivery was carried out every three month.

\section{Drug Planning and Schedule of Activities for Preparing Operational work Plans}

Planning is the basic foundation of the overall management function and can be process of achieving the goals of the health center effectively and efficiently (Sulaiman, 2011).

The result of the research revealed that drug needs planning of the pharmacy installation of the health center in the working area of Klaten District Health Office was carried out by the drug manager himself and there was something done by a team between the drug manager and the pharmacist assistant or pharmacist with the health center of treasurer. From the observation method it is know that on average each health center has only one pharmacy worker. There were still a lack of staff who helped in the process of managing drugs disclosed by several informants.

In a previous research by Ingrid N. Rumbay (2015) it was stated that pharmacy work at the UPTD Minahasa District Health Office all of which were carried out by pharmacists, start from recording reporting, receiving goods, storing, distributing and reporting.

\section{The Method Used for Planning for Drugs Procurement}

Drug procurement at the health center conducted to obtain the types and quantities of drugs, high quality drugs, guarantee the availability of drugs quickly and on time. Therefore the drug procurement must pay attention and consider that the drugs held are in accordance with the type and amount of drugs planned (Djuna et al, 2014).

The result of the research revealed that the drug procurement was carried out by using drugs or consumption methods in accordance with needs of the drug every month at the health center. This is different from the results of Malasari et al (2016) research about Analysis of the Implementation and Drug Procurement at the Modayag Health Center which states that planning of drug needs in the Modayag Health Center uses a combination of consumption methods and epidemiological methods.

\section{Drug Procurement at the Health Center Pharmacy Installation}

The resutl of the research revealed that the health center could conduct the procurement of their own drug through the National Health Insurance (JKN) capitation fund. Drug prourement is carried out once a year with a one and a half year buffer stock through e-catalogs outside the procurement provided by Phrmacy Installation Health Office. Drug procurement is done by considering the doctor's proposal.

Different from Iwan Indriawan et al (2014) research about Drug Management Analysis at Gaya Baru V Health Center Sub-district Bandar Surabaya, Central Lampung District in drug procuring/ requesting at Gaya Baru Health Center only submitting drug request to GFK Installation and not 
justified buying outside. Drug procurement at the health center only submits routine requests to GFK every 3-4 months.

\section{Spatial Arrangement and Drug Storage}

Storage is an activity of storing and maintaning by placed drugs and drug supplies received in a place that considered safe from theft and physical disturbances that can damage the quality of drugs and drug supplies (Ministry of Health, 2010). Drugs storage is a process from the beginning of receiving the drug, storing the drug and sending the drug to the service unit (Qiyaam et al, 2016).

Result of the research revealed that the spatial arrangement and drug storage had been carried out properly in accordance with the procedure by the drug manager, where the drugs were storaged in a separate room with the preparation of drug stock using FIFO FEFO system, separated according to preparation and arranged alphabetically to facilitate search during service. This is in line with Mangindara (2012) researh which the preparation of drug stocks in pharmacy warehouse at Kampala Health Center is made alphabetical order and uses FIFO FEFO method.

\section{Safeguarding the Quality of Drug}

Drug storage is a regulatory activity for the drugs received so that they are safe (not lost), avoid physical and chemical damage and their quality is guaranteed in accordance with the requirements set. The aim is the quality of the drugs available at the health center can be maintaned according to the requirements (Rismalawati et al, 2015).

The results of the research showed that the drug manager kept the drugs in a separate room and closed room with air conditioner or fans, the drug is also stored on pallets, shelves, refigerators or chain cold. To maintain the quality of the drug, the drug manager of the health center has also separated the drug according to the dosage form.

From the observations of researchers to the health center storage warehouse, both health centers that already have air conditioner or health centers that use fans have not yet had temperature measurements and recording room temperature as recommended by the Ministry of Health.

\section{Examination of Drug that Come}

Drug distribution aims to meet the drug needs of sub health service units in the working area of the health center with the type, quality and right time (Ministry of Health, 2010). From the result of the research, the drug is coming at the health center pharmacy installation were examined by responsible person for drug manager, checked one by one from the name of the drug, number, batch number, volume and expiration date according to the invoice or drug delivery letter by the drug manager or the Official Who Receives the Work (PPHP).

\section{Drug Distribution Mechanism at the Health Center Pharmacy Installation}

Result of the research revealed that drug distribution from health center to auxiliary health centers and PKD was done once a month using LPLPO then the drugs were provided on request taking into account the availability of drug at the health center. Drug distribution can also be done every two months because of the large number of units available.

This is different from the Rismalawati et al (2015) research about the Study of Drug Management in the Lawa Health Center West Muna District in 2015 where the results of this research revealed that the drug distribution was carried out every day directly to patients because the Lawa Health Center did not have other health center networks.

\section{Drug Needed by the Health Center}

District Pharmacy Installation carry out drug distribution to the health center in their working area according to the needs of each Health Service Unit (Ministry of Health, 2010). Drug needs at the health center pharmacy installation come from drug office and self drug procurement.

Result of the research revealed that drug distribution from the office came once a month on a regulary accordance with requests submitted by drug manager of the health center. From the results of triangulation to the Head of the Pharmacy Installation of Klaten District Health Office, drug delivery is based on incoming reports in advance taking into account the distance of drug delivery. 
Setyadi and Sugiyanto (2011) research about Discription of Planning Drug Needs at Semarang Disrict Health Center also revealed that the drug distribution schedule is two month but if certain conditions accur the health center are allowed to request outside the distribution schedule.

\section{System for Recording and Repoorting Drug at the Health Center Pharmacy Installation}

Result of the research revealed that drug recording and reporting at the health center pharmacy intallation had used a sympus. Sympus is a software that provides various types of report menus that function to make several types of reports. The use of sympus in some health center has no run optimally because it is constrained by insufficient labor and servers. Recording and reporting of drugs in auxiliary health center and other units are still manually using LPLPO and made on a daily and monthly basis.

This research also contradicted Setyadi and Sugiyanto (201) research about Description of Planning Drug Needs at Semarang District Health Center where this reserarch revealed that LPLPO was made every December, at the end of each year.

\section{CONCLUSION}

Drug management at the health center pharmacy installation working area of Klaten District Health Office start from planning carried out every month and supported by drug procurement each year using consumption method. Drug storage at the health center pharmacy installation is accordance with the procedure. Safeguarding the quality of the drug at each drug storage there is no drug temperature recorder and room. Drug distribution is carried out by office to the health center and followed by distribution of health center to auxiliary health center and other units. Drug recording and reporting at the health center has used sympus even though some have not been optimally while in the auxiliary health center and other units are still manually using LPLPO. Suggestions for researchers furthermore need research on drug management by using different time periods with other methoods so that new phenomena emerge.

\section{REFERENCES}

Anshari, Muhammad. (2009). Aplikasi Manajemen Pengelolaan Obat dan Makanan. Yogyakarta: Nuha Medika.

Djuna, S., Arifin, M.A \& Darmawansyah. (2014). Studi Manajemen Pengelolaan Obat di Puskesmas Labakkang Kabupaten Pangkep. Makassar: Universitas Hasanudin.

Herlambang, S. (2016). Manajemen Pelayanan Rumah Sakit. Yogyakarta: Goosyen Publishing.

Indriawan, I., Wahyudi, Tri W., \& Agustina, R. (2014). Analisis Pengelolaan Obat di Puskesmas Gaya Baru V Kecamatan Bandar Surabaya Kabupaten Lampung Tengah. Jurnal Kesehatan Holistik Volume 8:1-6.

Kementerian Kesehatan. (2006). Keputusan Menteri Kesehatan Nomor 189/Menkes/SK/III/ 2016 tentang Kebijakan Obat Nasional. Jakarta: Kementerian Kesehatan.

Kementerian Kesehatan (2008). Keputusan Menteri Kesehatan Nomor 1121/Menkes/SK/ XII/2008 tentang Pedoman Teknis Pengadaan Obat Publik dan Perbekalan Kesehatan untuk Pelayanan Kesehatan Dasar. Jakarta: Kementerian Kesehatan.

Kementerian Kesehatan. (2010). Materi Pelatihan Manajemen Kefarmasian di Instalasi Farmasi Kabupaten/Kota. Jakarta: Direktorat Jenderal Bina Kefarmasian dan Alat Kesehatan.

Malasari, Duwiki, D., Maramis, Franckie, R., \& Paul, A. (2016). Analisis Pelaksanaan Perencanaan dan Pengadaan Obat di Puskesmas Modayag. Manado: Universitas Sam Ratulangi.

Mangindra, dkk. (2012). Analisis Pengelolaan Obat di Puskesmas Kampala Kecamatan Sinjai Timur Kabupaten Sinjai Tahun 2011. Jurnal AKK, Volume 1 Nomor 1: 31-40. 
Qiyaam, N., Furqoni, Nur \& Hariati. (2016). Evaluasi Manajemen Penyimpanan Obat di Gudang Obat Instalasi Farmasi Rumah Sakit Umum Daerah dr. R. Soedjono Selong Lombok Timur. Jurnal Ilmiah Ibnu Sina. Volume 1: 61-70.

Rismalawati, Hariati, L. \& Ahmad, Ali Imran. (2015). Studi Manajemen Pengelolaan Obat di Puskesmas Lawa Kabupaten Muna Barat Tahun 2015. Jurnal Ilmiah Mahasiswa Kesehatan Masyarakat, Volume 1: 1-9.

Rumbay, Ingrid, N., Kandou, G., D., \& Soleman, T. (2015). Analisis Perencanaan Obat di Dinas Kesehatan Kabupaten Minahasa Tenggara. Jurnal Ilmu Kesehatan Masyarakat Unsrat, Volume 5 No 2b: 469-478.

Setyadi, Ardani, A. \& Sugiyanto. (2015). Gambaran Perencanaan Kebutuhan Obat di Puskesmas Kabupaten Semarang. Semarang: Universitas Dian Nuswantoro.

Sulaiman, \& Sutisna, E. (2011). Manajemen Kesehatan. Yogyakarta: Gajah Mada University Press. 